\title{
HOUSEHOLD PREPAREDNESS FOR FLOOD DISASTER IN SURAKARTA CITY 2017
}

\author{
Ika Rahmawati' ${ }^{1)}$, Chatarina Muryani ${ }^{2)}$, Setya Nugraha ${ }^{3)}$ \\ 1) ,2),3) Departement of Geography Education, Universitas Sebelas Maret, Surakarta, Central \\ Java, Indonesia \\ Email : ikarahmawati6995@gmail.com
}

\begin{abstract}
This research case aims to determine (1) The spread of floods in the city of Surakarta in 2016; (2) Uncertainty factors that causing floods based on community perception in Surakarta City; (3) Individual and household preparedness levels in dealing with flood disaster in Surakarta City; (4) Implementation of science as a teaching material of geography in grade XI Senior High School on basic material of natural disaster mitigation.

The research was conducted in Western City of Surakarta. The area assumed in Western City of Surakarta are Banjarsari district, Laweyan District, and Serengan District. Eligible samples consisted of 11 villages affected by flood in 2016, sampling of administrative unit using purposive sampling technique. The sample has been taken is the number of individuals / households in each ' $\mathrm{RW}$ ' affected by floods in each villages, the number of samples is using snowball sampling technique. Data collection was done by documentation study, interview, questionnaire, and interview. Data validity test is done by data triangulation method. Data analysis is using Likert approach and LIPI preparedness measurement framework - UNESCO / ISDR.

The results of the research are as follows: (1) flooding spread in eleven sub-districts in West Surakarta City which is divided into 3 regions based on administrative unit of analysis. Banjarsari District having local flood characteristics and submissions with elevation and duration of time falling into the low category. Laweyan District areas have local flood characteristics and postings with elevation and duration of time that falling into the low category. Serengan District has local flood characteristics and post with elevation and duration falling into the medium category; (2). Factors causing high flooding, garbage disposal, and flood control building conditions; (3) Individual and household preparedness studies in all villages are in a ready category;
\end{abstract}

\section{Keywords: Preparedness, Disaster, Flood, Perception}

\section{INTRODUCTION}

Flood is one of natural disaster which comes often in Indonesia, especially in the big cities. Flood is an overflow water that hit areas along river banks, lowland as shettlement, rice fields, plantations, and other productive land which can cause physical and material losses. Dibyosaputro (1984) in Soemantri (2008 : 3) concisely summarized causing flood and the duration of inundation are not only caused by overflow of river water, but by excess rainfall and fluctuations in sea level, especially the alluvial coastline, geomorphological units such as swamps, back swamp, floodplain, the confluence of 
rivers with alluvial plains is flood prone places.

Surakarta City which is included in administrative region of Central Java Province become one of the cities in flood prone area. Surakarta City seen from geomorphological point of view is a basin area located between mountains and hills or often called an intermountain basin which is in a depression zone between the plateau in the south (Wonogiri), Mount Merapi and Merbabu in the west, Kendeng Hills in the north, and Mount Lawu in the east.

The big chance of flooding when rainy season in Surakarta city caused by primary river Bengawan solo dan secondary river such as Sumber, Anyar, Pepe, Jenes, Pelem Wulung which are the stream pass Surakarta City. Furthermore, the morphological conditions of Surakarta City which is basin area and traversed by rivers that have the upper in mountains and hills overlooking Surakarta City. So, when rain occurs some rainwater will flow to the city through rivers which flows in Surakarta City.

The city of Surakarta had experienced major floods including in 1966, 2007, 2009 and 2016. Seeing several flood events that occurred in Surakarta City, flooded areas can be different in each year. Some areas in the eastern city of
Surakarta which are located in the Bengawan Solo flood plain, including the Pucang Sawit, Sewu, Semanggi and Sangkrah Subdistricts are flooded subscriptions every rainy season. Because it often experiences flooding, it will naturally make the community that has important knowledge in flood preparedness.

The condition in Eastern City of Surakarta not the same as west region, where the flood in wetern region has a type of flood shipment. Rarely tradition of flood and there are suffice flood infrastructures make most of the community in western region feel always safe from flood hazard. Even though when rainy season come, shipment flood can hit area along river anytime and unpredictable.

The research just conducted in Western City of Surakarta. The area assumed in Western City of Surakarta are Banjarsari District, Laweyan District, and Serengan District which several of secondary river such as Pepe, Sumber, Anyar, Gajah Putih, Premulung, and Jenes pass this area. According to data that released by Surakarta Regional Disaster Management Agency (Badan Penanggulangan Bencana Daerah Surakarta), flood prone area in the Western City of Surakarta include 11 villages. 
The number of flood prone area in Banjarsari Sub-district are 5 include Banyuanyar, Kadipiro, Sumber, Nusukan, and Gilingan that passed by river stream Pepe, Sumber, Anyar, and Gajah Putih. Laweyan Sub-district are 4 include Pajang, Sondakan, Laweyan, and Bumi that passed by river Pelem Wulung and Serengan Subdistrict are 2 include Tipes and Joyotakan that passed by river Tanggul, Jenes, and Wingko.

Eleven district were chosen as research location because it is part of the Surakarta City which has a vulnerability to flooding that increeasing from previous years. Increased vulnerability regadless from the unplanned development of the city where urban landuse such as settlement, industrial, and services getting dominant on the one hand, and on the other hand increasingly cramped of the open space that function as a water catchment area.

Flooding should not only be seen as merely natural physical phenomena, but it also has socio-economic implications. Flood will be meaningless if there is no effect on humans and all of socioeconomic activities. Floods are considered as a disaster if causing in human casualties, environmental damages, property losses, and psychological impacts. Disruption of human activities, loss of property, life, and environment is an interaction of physical phenomena with socio - economics (Setiyarso, $2009: 3$ ).

The impact caused by floods in Surakarta City can be reduced by increasing community preparedness to face the floods. Laws of the Indonesian Republic Number 24 in 2007 about disaster management explisitly exposed that disaster preparedness is one of sequence which done to anticipate disasters through organizing a proper and efficiency steps.

Preparedness to face the flood diaster need to be noticed to find out how far the level of preparedness and public awareness responds the hazard of flood disaster. Both local and shipment floods that previously occured in Surakarta City, namely in 2016 gave an overview that floods can be repeated in the following years such as 2017. Therefore, public preparedness needs to be seen periodically because it a dynamic or can change at any time.

Public perception also contribute to efforts improve disaster preparedness Schremerhorn (2010) argues perception is a proccess where someone choose, interpret, construe, and respond to information comes that from the environment around (in Harliani 2014 : 42). Furthemore Sarwono (2010: 86) 
explain within someone perception a though process occurs which in the end realize an understanding.

Individuals in community have differencial insight and perception about environmental issues, as the factors that causing flood. Public perception toward factors that causing flood is important because will determine the efforts that can be taken to reduce disaster hazard. If risk perception of persons living in prone areas is known, effective disaster management strategies for mitigation measures can be more effectively designed (Mishra et al, 2010 : 39). Based on these background, the research case aims to determine :

1. The spread of floods in Surakarta City in 2016

2. Uncertainty factors that causing floods based on community perception in Surakarta City

3. Individual and household preparedness levels in dealing with flood disaster in Surakarta City

\section{METHODOLOGY}

The research used survey method in the field to obtain information about the object of study through structured interview using questionnaires and documentation. This research used spatial approach. The context of spatial approach includes differences in the appearance of structures, patterns, and processes. Spatial data in this study is the distribution of flood areas, perceptions of factors causing flood, and individual and household preparedness to face flood.

The result of processing spatial data is a geographic maps or thematic maps that can present one theme or multithema as a description, analysis, and synthesis of objects or spatial phenomena (Hadi : 2017) in this case the preparedness of individuals and household to face floods in Surakarta City.

Data collection was done by documntation study, interview, questionnaire, and interview. Data needed include primary and secondary data. Primary data include the location affected by flood, land cover, flood elevation, absolute location, knowledge and attitude, absolute location, emergency planning, early warning system, resources mobilization capacity, and factors that causing floods. Secondary data includes administration boundaries, rainfall, land use, and population data.

Distribution of flood was done by taking the secondary data from the related departement include Regional Disaster Management Agency (BPBD), Bengawan Solo River Basin Organization (BBWS Bengawan Solo), Office of Public Work (DPU). Field checking and interview using questionaire with community affected by 
flooding was done to obtain more accurate description of flood distribution. Data is processed using Geographic Information System (GIS) with analysis tools ArcGIS 10.2 program resulting flood distribution map scale $1: 45.000$ which shows the location affected by floods and the characteristics of floods (long of inundation and water level) symbolized by the color field.
The assesment used to measure perception based on the Likert scale assesment. Perception instrument are arranged as clossed statements with four multilevel alternative answers. The first step to calculating perception is to determine the interval class on indicators of the causes of flooding; the second makes the answer categories of flood causing indicators, as presented in table 3.1 :

Table 3.1 Response Categories Indicators of Flood

\begin{tabular}{cl}
\hline Score & Class Categories \\
\hline $3,25<\mathrm{x} \leq 4,00$ & Strongly Agree \\
\hline $2,50<\mathrm{x} \leq 3,25$ & Agree \\
\hline $1,75<\mathrm{x} \leq 2,50$ & Disagree \\
\hline $1,00<\mathrm{x} \leq 1,75$ & Strongly Disagree \\
\hline
\end{tabular}

Source : Primary Data Calculation, 2017

Statement with class category strongly agree are considered to be the most dominant factor causing flood while the class categories disagree and strongly disagree is considered to be a factor that causing flood that is not dominant based on community perceptions; the third calculate the value of the indicators that causing flood. The result of questionnaire analysis is total values in each statement of the factor causing flood. Total value in each statement presented in table form then graphed that shows the difference in the respondent's answer to the statement of the factors causing flood.

The analysis used to determine the level of preparedness using disaster preparedness index analysis by The Indonesian Institute of Science (LIPI) UNESCO/ISDR. The framework designed by LIPI - UNESCO/ISDR has four preparedness parameters such as knowledge and attitude; emergency planning; early warning system; and resource mobilization capacity. The step for obtaining individual and household preparedness index values the first step is to determine the index parameter using the formula :

$$
\begin{aligned}
& \text { Parameter Index } \\
& =\frac{\text { Real parameter total score }}{\text { Maximum score parameter }} \times 100
\end{aligned}
$$


Second calculates a combination parameter index using a combination index weighed, the formula :

$=0,45 *$ indeks $\mathrm{KA}+0,35 *$ indeks $\mathrm{EP}+$ 0,15 *indeks RMC $+0,05 *$ indeks WS

Description :

KA : Knowledge and Attitude

EP : Emergency Planning

RMC : Resource Mobilization Capacity
WS : Warning System

Then calculate the index of whole sample by adding the index of all sample divided by the number of samples. Level of preparedness in this research refers to the classification by LIPI-UNESCO/ISDR (2006) which categorize the level of preparedness into five :

Table 3.2 Classification of Preparedness Levels

\begin{tabular}{ll}
\hline Index Number & Category \\
\hline $80-100$ & Very Ready \\
$65-79$ & Ready \\
$55-64$ & Almost Ready \\
$40-54$ & Less Ready \\
$<40(0-39)$ & Not Ready \\
\hline
\end{tabular}

Source : LIPI-UNESCO/ISDR (2006)

Research themes about individual and household preparedness to face of flood disaster becomes the supplement material in learning activities accordance with geography syllabus of the XI Senior High School in semester even 2013 curriculum. Basic competencies related with the application of the research are analyze types and mitigate natural disasters. Implementation of research is first compiled teaching materials.

\section{DISCUSSION AND RESULT}

\section{The Spread of Floods in Surakarta} City in 2016

Floods in Surakarta City spread across three regions. Regional spread is based on the analysis unit of administrative. The following is an explanation of the characteristic flood in each region :

a. Region of Banjarsari District

The area included the Banjarsari District are 5 subdistrict, namely Banyuanyar, Nusukan, Sumber, Kadipiro, and Gilingan Subdistricts. The five subdistrict were passed by Sumber River, Pepe River, Anyar River, and Gajah Putih River. Banjarsari District having local and shipment flood characteristic.

Type of flood that was sent by the overflow of Pepe Ribver which has upstream in Boyolali Regency. This type of shipment flooding 
inundated the entire subdistrict that was the location of the research. In addition of shipment flood, in 2016 floods with local types also inundate two sub district in Banjarsari region, including Banyuanyar and Kadipiro Subdistrict. Local floods caused by high intensity rain in Surakarta City. Surface runoff in the area greater than the capacity of existing secondary and tertiary channels.

Relating to flood characteristics such as altitude or flood elevation and duration of the event shows a variation numbers. Flood elevation in Banjarsari District regions are in the range of $0,5-1,5$ and the duration of floods in five subdistrict is $0,5-1$ day. Both elevation and duration of flood in Banjarsari District falling into low category.

b. Region of Laweyan District

Laweyan District includes Pajang, Sondakan, Laweyan, and Bumi Subdistrict. Flood occure in Laweyan District have local and shipment characteristic. The type of shipment in 2016 caused by water discharge from Sukoharjo Regency because the high rainfall in Sukoharjo, resulting in overflowing Pelem Wulung River. Local flood generally caused by rain in Surakarta City which result in greater surface flow compared to the channel capacity.

Based on the result of the study, it can be seen that overflows river water and inundates public settlement has a elevation between $0,5-1,5$ meters and the average duration for inundation is $0,5-1,5$ days and post with elevation and duration falling into the low category.

c. Region of Serengan District

The area included the Serengan District are Tipes and Joyotakan subdistrict. Flood occure in Serengan District have local and shipment characteristic. Shipment flood from macro system channels in Surakarta City, namely Bengawan Solo and secondary channels that entered Bengawan Solo resulting in a backflow from secondary channel and causing flood in region around. This flood called back water.

Local flood caused more by the high intensity of the rain and found a ogap between rain discharge and the capacity of the micro system channel. The 
elevation flood in Joyotakan

Subdistrict reaches meters and it takes 2 days to recede. Duration of the inundation time was longer because it was directly affected by Bengawan Solo overflow and was strongly affected by the back of secondary channels that entered Bengawan Solo. The spread of flood in research sites is visualized in map 1.

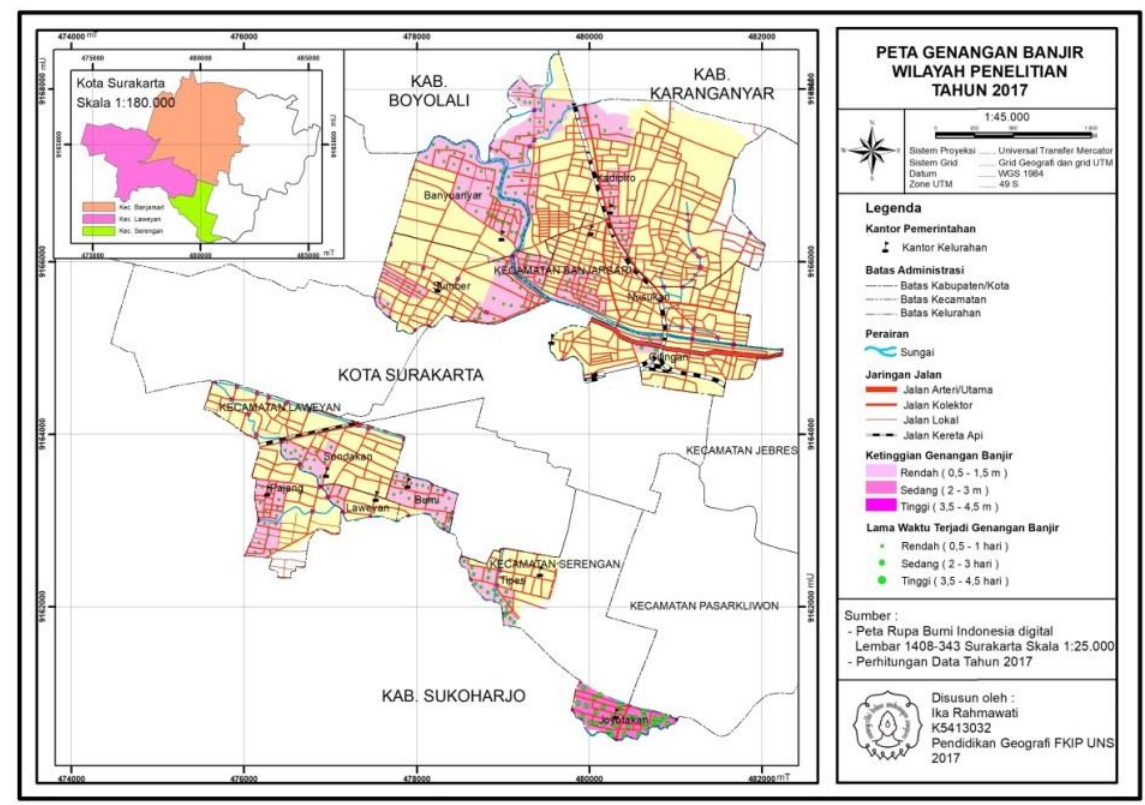

Map 1. Map of the flood spreads in Surakarta City 2016

2. Factors that Causing Floods Based on Community Perception in Surakarta City

Community perception studied in this research relate to the thoughts or opinion of flood affected communities regarding the factor that causing flood. The result of the research community perceptions in Surakarta City have differences between one region and another even though in the region has a same vulnerability to flood disaster. In the result of study community perceptions there are 3 most dominant factors causing flood.

Looking at the most dominant factors causing flood in each region can be grouped in two. First because of natural factors such as high rainfall intensity and second non natural factors such as garbage disposal and the condition of existing flood control have decreased in capacity. According to Chen et al (2016 : 4) evaluation of community perceptions to the factors causing flood can relate to disaster risk. Knowledge about the factors 
causing flood needed to inform policy makers take actions to flood risk reduction.

The government as a policy maker has made efforts to reduce flood risk. But so far flood control that have been carried out are more emphasized on structural efforts. A structural efforts will function optimally if balanced with non structural efforts and can support or strengthen existing structural policies. This effort needs to be supported by coummunity readiness to face flood hazard and overcome the risk faced.

\section{Individual and Household}

\section{Preparedness Level in Dealing with} Flood Disaster in Surakarta City

Individual and household preparedness level in Surakarta City are in a ready. Four parameters used to see the level of household preparedness are knowledge and attitude, emergency planning, warning system, and reaction mobilization capacity. The four parameters that have the highest value are knowledge and attitudes in a very prepared condition. The parameter with the lowest value is resources mobilization capacity in almost ready category. Other parameters are emergency planning and warning system in each category almost ready and ready.

The level of knowledge and attitudes of individual and household in dealing with flood disaster falls into very prepared category, this is because average of community knows the potential for flood disaster that occur in Surakarta City area, knows causing of flood, sign before the floods, and the impact caused by flood disaster. This condition caused by flood experience that has been felt by community, so they can learn from previous the great flood events. When there are signs of flooding, the community also understands the right actions to be taken to minimize the risk of flooding that might occur.

Knowledge and good attitude toward floods have a positive influence on community emergency response plans. Community in research location has had several emergency response efforts such as availability of alternative communication tools ready to use when floods occur, having first aid kit, and having received material on dealing with flood. The efforts that need to be disseminated to public are importance to having important telephone numbers such as hospitals/Indonesian Red Cross/Search 


\section{And Rescue/ Regional Disaster}

Management Agency and preparing disaster alert bags. Dissemination by the government and Regional Disaster Management Agency on preparedness in Surakarta City alo needs to be improved so that more evenly distributed in each flood affected area.

Good knowledge and emergency planning in Surakarta City have not been equipped with sufficient warning system and reaction mobilization capacity, it proven that the level of preparedness in parameter is in the almost ready category. The thing that needs attention related to disaster warning is the limited understanding of community regarding warning system, especially those based on technology. Reaction mobilization capacity index at the research location also falls into almost ready category. Individuals/households still in post flood recovery activities. Result of individual and household preparedness is presented in map 2.

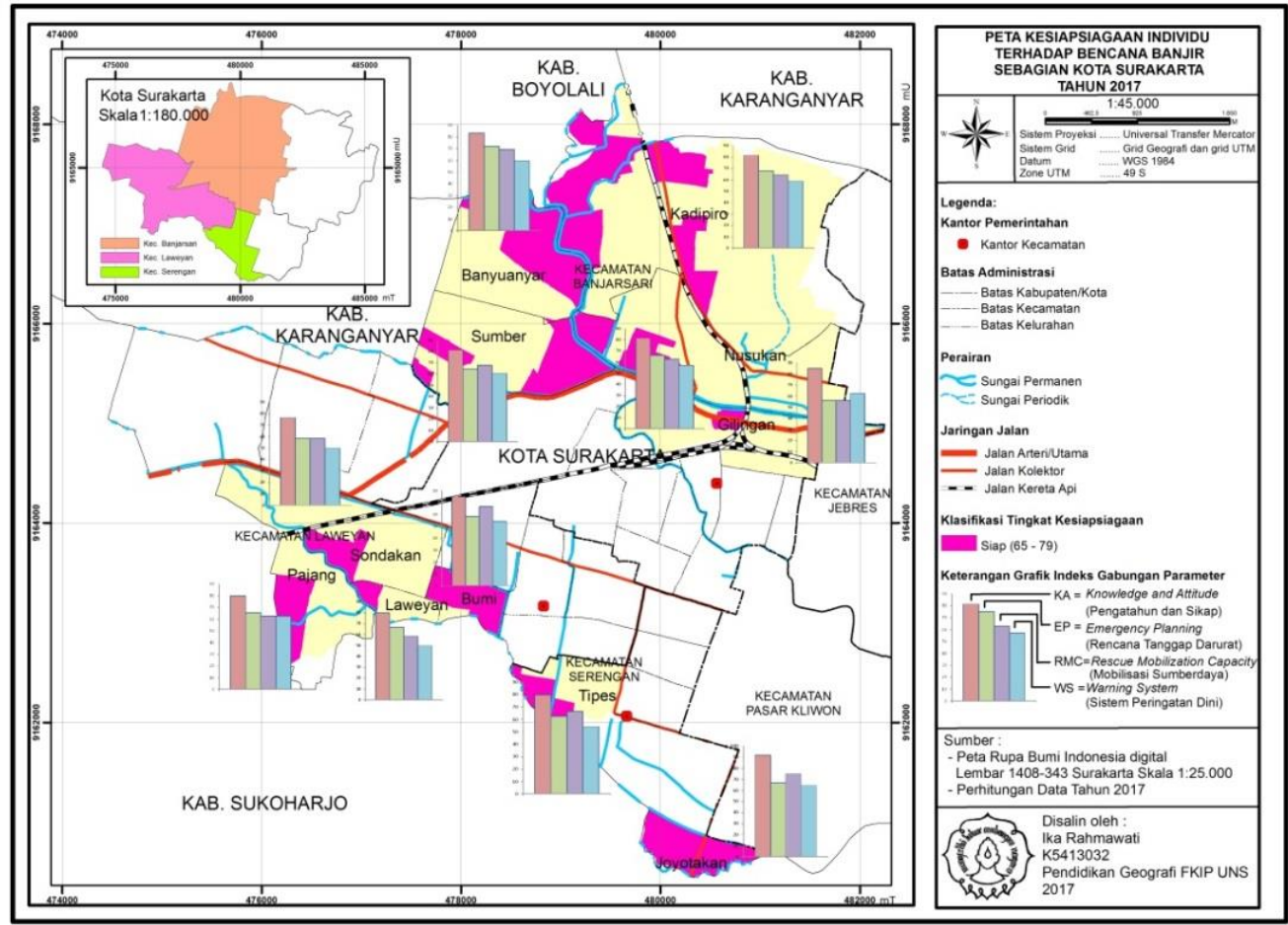

Map 2. Individual and Household Preparedness in Surakarta City

\section{CONCLUSION}

1. Flooding in 2016 spread in eleven subdistricts in Surakarta City which is divided into 3 regions based on the administrative unit : a. Banjarsari District Area includes Banyuanyar, Nusukan, Gilingan, Sumber, and Kadipiro Subdistrict having local and shipment flood characteristic and submissions with 
elevation and duration of time falling into the low category

b. Laweyan District Area includes Pajang, Bumi, Sondakan, Laweyan Subdistrict have local and shipment flood characteristic and postings with elevation and duration of time that falling into the low category

c. Serengan District includes Tipes and Joyotakan Subdistrict have local and shipment flood characteristic and postings with elevation and duration of time that falling into the middle category

2. Factors that causing flood based on community peceptios in Surakarta City can be grouped into two, first because of natural factors, high rainfall intensity. Second, non natural factors such as garbage disposal and condition of existing flood control buildings have decreased in capacity

3. Individual and household preparedness in Surakarta City has preparedness that is in the ready category. Individuals and household with preparedness are ready to have knowledge of flood disaster and in emergency planning, but not yet maximally aware of exixting warning system and taking actions such as reaction mobilization capacity.

\section{REFERENCES}

Botzen WJW, Aerts JCJH, \& Van Den Bergh JCJM. 2009. Dependence of Flood Risk Perceptions on Socioeconomic and Objective Risk Factors. Water Resource Research Vol 45, No 1, 1 - 15

Cahyadi, Rusli \& Agustina Situmorang. 2008. Kesiapsiagaan Masyarakat dalam Mengantisipasi Bencana Alam di Kabupaten Serang. Jakarta : Pusat Penelitian Oseanografi LIPI

Carter, W. Nick. 2008. Disaster Management : A Disaster Management Handbook. Philippines : Asian Development Bank

Chan, Emily YY, Janice SK Yue, \& Poyi Lee. 2016. Socio - Demographic Predictors for Urban Community Disaster Health Risk Perceptions and Household Based Preparedness in a Chinese Urban City. Diunduh pada 12 Juni 2017, dari https://ora.ox.ac.uk/

Dodon. 2013. Indikator dan Perilaku Kesiapsiagaan Masyarakat di Permukiman Padat Penduduk dalam Antisipasi Berbagai Bencana Banjir. Jurnal Perencanaan Wilayah dan Kota, Vol. 24, No. 2, $125-140$

Hadi, Partoso. 2017. Esensi Peta. Diunduh pada 10 Juni 2017, dari https://partosohadi.wordpress.com/ 2017/05/11/esensi-peta/

Hidayati, Deny. 2015. Community Preparedness : A New Paradigm In Disaster Management in Indonesia. Yogyakarta : UGM Press 
Kodoatie, J. Robert. 2013. Rekayasa dan Manajemen Banjir Kota. Yogyakarta : Penerbit Andi

Setiyarso, Budi. 2009. Studi Reaksi Manusia terhadap Bahaya Banjir Kota Surakarta. Skripsi. Surakarta : FKIP UNS

Sudibyakto. 2010. Penyusunan Standar Prosedur Operasional untuk Kesiapsiagaan dan Tanggap Darurat Bencana Banjir di Indonesia. Laporan Penelitian. Yogyakarta : LPPM UGM

Undang - Undang Republik Indonesia Nomor 24. 2007. Penanggulangan Bencana 